\title{
Biochemical and physiological modifications in tissues of Sardina pilchardus: spatial and temporal patterns as a baseline for biomonitoring studies
}

\author{
Bruno S. Nunes *, Rita Travasso, Fernando Gonçalves and Bruno B. Castro \\ Departamento de Biologia, Centro de Estudos do Ambiente e do Mar (CESAM), Universidade de Aveiro, Aveiro, Portugal
}

Edited by:

Aziz Ullah, Kohat University of

Science and Technology, Pakistan

\section{Reviewed by:}

Peddrick Weis, Rutgers-New Jersey

Medical School, USA

Alexa C. Alexander, Environment

Canada, Canada

*Correspondence:

Bruno S. Nunes, Departamento de

Biologia, Centro de Estudos do

Ambiente e do Mar (CESAM),

Universidade de Aveiro, Campus

Universitário de Santiago, 3810-193

Aveiro, Portugal

e-mail:nunes.b@ua.pt
Sardina pilchardus is a marine species common in the North Atlantic Ocean, and is subjected to diffuse anthropogenic chemical contamination and seasonal fluctuations in biotic and abiotic parameters that may alter its physiology and condition. Biological material is easily available through commercial fisheries, which could facilitate its use as a bioindicator species. The aim of the present work was to address its potential inclusion in biomonitoring studies, considering a combinatory approach through the use of enzymatic biomarkers and somatic indices, by assessing spatial and temporal patterns in a metapopulation along the west coast of Portugal. Our results showed significant variability of the biochemical and physiological profile of the fish, mainly concordant between sampling sites. Large differences for most markers were found across periods of the year, showing the importance of seasonality, which was mostly related to the reproductive cycle. Hence, environmental scientists should acknowledge seasonality as a strong driving force for physiological adaptations, influencing biochemical markers that are normally used to identify effects of chemical contamination. The here-obtained set of data suggests that $S$. pilchardus may be successfully included in oceanic biomonitoring studies, when one considers that the contribution of seasonal factors may exceed the influence of eventual anthropogenic contamination.

Keywords: sardine, biomarkers, seasonality and natural variation, physiology and reproduction, diffuse pollution, biomonitoring

\section{INTRODUCTION}

The use of biomarkers is nowadays important in environmental monitoring programs, and also as early warning signals of environmental distress (Cajaraville et al., 2000; Lam and Gray, 2003; Tsangaris et al., 2010; Fonseca et al., 2011). These tools may provide an indication of the physiological status of organisms and populations, identify seasonal and spatial trends, thus allowing a multi-scale assessment of ecosystem quality, which is useful for ecophysiological and ecotoxicological studies (Peakall, 1992; Heath, 1995). Biochemical markers, more than just signaling the presence of foreign chemicals with biological activities, may give specific insights into processes and mechanisms that are impaired or modified by the contribution of a large set of factors. Among causal factors of the modification of biomarkers, one can find a multiplicity of sources, both of human but also of natural origin. A comprehensive battery of different biomarkers is appropriate to quantify overall biological effects under the challenge of multiple stressors. Many stressors (including pesticides, drugs or metals) exert their activity by acting on the central nervous system, causing neurotoxicity; to address neurotoxicity, caused by accumulation of excess of acetylcholine, cholinesterasic inhibition is a suitable tool (Nunes, 2011). Hypoxia of marine organisms has also been associated to stress (Fischer et al., 1992; Yang et al., 1992); lactate dehydrogenase (LDH) is an important glycolytic enzyme that may be induced when organisms are exposed to low levels of oxygen (Wu and Lam, 1997) or contaminants. LDH activity can function as a marker to assess the respiratory status of organisms (Antunes et al., 2010). The use of biotransformation enzymes, namely phase II (conjugation) enzymes, has been common in several environmental studies (Le Pennec and Le Pennec, 2003); among conjugation enzymes, GSTs activity has assumed a prominent role, which is of fundamental importance in the metabolism of most classes of marine contaminants, but also of endogenous chemicals produced during specific phases of the life cycle of living organisms (Josephy and Mannervick, 2006). As a response to exposure to electrophilic compounds, GSTs activity may suffer induction at the DNA level (van der Oost et al., 2003; Domingues et al., 2010). Multiple agents (including contaminants and intense metabolic activity) cause oxidative stress, through the formation and release of reactive oxygen species (ROS), which can in turn react with intracellular critical macromolecules, leading to enzymatic inactivation, DNA damage and cellular death (van der Oost et al., 2003). Antioxidant enzymes are important in terms of controlling the effects of ROS (Lionetto et al., 2003); catalase (CAT), for example, catalyzes the dismutation of hydrogen peroxide in water and oxygen (Chi et al., 2010). Numerous field studies have demonstrated the usefulness and responsiveness of a battery of biomarkers in 
natural populations subjected to multiple stresses (Ramos et al., 2014).

Other indicators are also useful to assess the physiological state of living organisms and can complement biomarker data. In fact, these indicators are also biomarkers, since they reflect measurable modifications in an organism's physiology. However, these parameters are more related to the physiological status, and result from the activation vs. depression of biochemical pathways whose modifications were primarily assessed using tools mentioned in the previous paragraph. Condition factors (ratios between the weight of the whole fish or specific organs and total body length: $\mathrm{K}, \mathrm{K}_{\text {gut }}, \mathrm{K}_{\text {liver }}$ ) reflect the energy balance of marine organisms, particularly fish, as well as their investment in reproduction and adverse environmental conditions (Yang et al., 1992; Nunes et al., 2011). Gonadosomatic and hepatosomatic indexes (GSI and HSI, respectively) are frequently determined in fish, and correspond to the relative weight of the gonads or the liver in comparison with total body weight (Fang et al., 2009). GSI is linked to reproductive function (Yang et al., 1992; Fang et al., 2009), being sensitive to spawning cycles, ovary development, and exogenous factorssuch as temperature and pollution (Sol et al., 2008). HSI provides information on fish nutritional status, because the liver is an important energy storage repository (Sol et al., 2008); additionally, changes in HSI may reflect challenges from extrinsic factors, such as toxicants and parasites (Fang et al., 2009; Yang et al., 1992).

Small pelagic fish species are key organisms in marine ecosystems, playing an important role connecting distinct trophic levels, due to their significant biomass in intermediate levels of food chains (Cury, 2000). They have also proven to be viable organisms in biomonitoring studies with physiological and biochemical markers (van der Oost et al., 2003; Peixoto et al., 2006; Stanic et al., 2006; see also previous paragraphs), which allow detecting ecosystem alterations (including pollution and seasonal fluctuations in abiotic parameters), but can also reflect the seasonal modification of the organism physiology, to cope with reproductive needs, for instance. According to Heath (1995), fish are privileged study objects in this field. Pelagic fish, in particular, are available all year long and in large amounts due to commercial fisheries, and this makes them particularly suitable as quality indicators of coastal areas. Notwithstanding, a large degree of natural variability is expected to occur in the physiological status of these organisms, due to resource and environmental fluctuations (e.g., upwelling and sea temperature regimes and their influence in plankton) and sexual or physiological condition (Ware and Thomson, 1991; Suthers, 1998). It is therefore necessary to tease out the influence of natural variability (e.g., spatial, seasonal) in selected biochemical and physiological markers before implementing them as biomonitoring tools.

The European sardine (Sardina pilchardus) is the traditional target of the important pelagic commercial fishing occurring in the Atlantic coast of the Iberian Peninsula (Chícharo, 1998; Mendes and Borges, 2006; Nunes et al., 2011), that uses mainly purse seining as fishing technique (Marçalo et al., 2006). According to recent data released by the Portuguese national agency that supervises fisheries (DGRNSSM, 2012), 57,287 metric tons of sardine were captured along the Portuguese coast in
2011. This species is characterized by rapid growth and short life cycle, but can reach a life expectancy of 9 years (Sinovčić et al., 2008). The geographical distribution of S. pilchardus is vast, from a southern limit located near Morocco/Mauritania to the northern limit at the English Channel/Ireland Sea; longitudinally, this species occurs from the vicinity of the Azores Islands to the East Mediterranean/Black Sea area (Stratoudakis and Silva, 2001). It is an omnivorous species, essentially filter feeder, with a diet mainly composed by mesozooplanktonic organisms (Costa and Garrido, 2004; Palomera et al., 2007). Mature individuals mate at the end of the first year of life (Stratoudakis and Silva, 2001) and the most active spawning period occurs when the temperature is comprised between 14 and $16^{\circ} \mathrm{C}$, which usually corresponds to winter and spring (Chícharo, 1998; Nunes et al., 2011). The physiological condition of $S$. pilchardus seems to be linked to its reproductive cycle (Amenzoui et al., 2006; Garrido et al., 2008; Nunes et al., 2011). Literature on the use of S. pilchardus as an environmental sentinel has shown its contamination by anthropogenic compounds, namely metals (Canli and Atli, 2003; Cabañero et al., 2005; Falcó et al., 2006), but also polycyclic aromatic hydrocarbons, polychlorinated biphenyls, and pesticides (Amado et al., 2006; Antunes et al., 2007; El Morsy et al., 2013). Some of these compounds, namely organochlorine pesticides, are not used in oceanic areas, and their presence in tissues of sardines captured at mid-Atlantic area (Azores Islands) demonstrates the global dispersion, and the validity of using S. pilchardus as an adequate tool to diagnose the presence of persistent anthropogenic compounds in the marine environment (Magalhães and De Barros, 1987). However, its use as a bioindicator is scarce and only a few studies have used a biomarker approach in this species-see Peters et al. (1994) for biotransformation and antioxidant enzymes in larvae.

The objectives of the present work were: (i) to assess the natural (seasonal) variability of physiological biomarkers in three subpopulations of S. pilchardus, captured in distinct locations; (ii) to verify if the natural variability is somehow connected to the nutritional and sexual cycles of the organisms along a period of 12 months; and (iii) to infer about the potential use of the hereselected battery of biomarkers for biomonitoring the quality of coastal waters.

\section{MATERIAL AND METHODS SAMPLE COLLECTION AND PROCESSING}

Sampling effort was undertaken in close cooperation with Docapesca - Portos e Lotas, SA, which is the Portuguese national company responsible for the management of commercial fish landing and selling. Individuals of $S$. pilchardus were monthly captured from May 2010 to May 2011 by coastal traditional commercial fishing vessels, by purse seining. This guaranteed that organisms were captured in distinct geographical areas, limited by the fuel autonomy and consequent operating range of commercial vessels. Fishing vessels were departing from Matosinhos $\left(41^{\circ} 11^{\prime} 0^{\prime \prime} \mathrm{N}, 8^{\circ} 42^{\prime} 0^{\prime \prime} \mathrm{W}\right)$, Aveiro ( $\left.40^{\circ} 38^{\prime} 40^{\prime \prime} \mathrm{N}, 8^{\circ} 44^{\prime} 0^{\prime \prime} \mathrm{W}\right)$ and Peniche $\left(39^{\circ} 21^{\prime} 20^{\prime \prime} \mathrm{N}, 9^{\circ} 22^{\prime} 20^{\prime \prime} \mathrm{W}\right)$ commercial harbors. Aveiro is roughly $84 \mathrm{~km}$ south of Matosinhos, while Peniche is $157 \mathrm{~km}$ south of Aveiro. It was thus possible to estimate a potential dispersion of more than $200 \mathrm{~km}$ between sampling sites. Immediately after capture, organisms were refrigerated $\left(4^{\circ} \mathrm{C}\right)$ until arrival to 
the commercial harbors to be landed. We had no involvement in the capture or transportation of fish, nor fish were especially captured for this study; the underlying idea is to use landed fish as a representative sample of local subpopulations in the scope of biomonitoring studies. Upon landing, a random sample of 10 adult sardines (total length $>15 \mathrm{~cm}$ ) per sampling site and period was processed for subsequent determination of physiological and reproductive state and enzymatic biomarkers. First, sardines were individually measured (total length), eviscerated and weighed (eviscerated weight). Organs were then dissected, and the gut, gonads, and liver were removed and weighed. Finally, specific organs were removed for enzymatic determinations: liver (GSTs and CAT), gills (GSTs), dorsal muscle (LDH), and brain and eyes (AChE). Tissue and organ removal was performed on ice and immediately stored at $-80^{\circ} \mathrm{C}$.

\section{NUTRITIONAL, PHYSIOLOGICAL AND REPRODUCTIVE STATE}

Condition factors were calculated for the overall individual $(\mathrm{K})$, and for specific organs ( $\left.\mathrm{K}_{\text {gut }}, \mathrm{K}_{\text {liver }}\right)$. The gonadosomatic (GSI) and hepatosomatic indices (HSI) were also calculated. These metrics were calculated according to the following equations:

$$
\begin{aligned}
& \mathrm{K}=\left(\text { eviscerated weight/total length }{ }^{3}\right) \times 1000 \\
& \mathrm{~K}_{\text {gut }}=\left(\text { gut weight } / \text { total length }^{3}\right) \times 1000 \\
& \mathrm{~K}_{\text {liver }}=\left(\text { liver weight/total length }{ }^{3}\right) \times 1000 \\
& \text { GSI }(\%)=(\text { gonad weight/eviscerated weight }) \times 100 \\
& \text { HSI }(\%)=(\text { liver weight/eviscerated weight }) \times 100
\end{aligned}
$$

All metrics used eviscerated weight instead of total weight, following Somarakis et al. (2004) and Nunes et al. (2011), in order to avoid interference due to stomach content, or due to increase of liver or gonad weight.

\section{ENZYMATIC ANALYSES}

The most prominent form of cholinesterase in the central nervous system of $S$. pilchardus is acetylcholinesterase (Contestabile and Zannoni, 1975). Samples (brain + eyes) were homogenized in ice-cold phosphate buffer $(0.1 \mathrm{M}, \mathrm{pH}=7.2)$ with a tissue homogenizer. Homogenized samples were then centrifuged for $3 \mathrm{~min}$ at $4^{\circ} \mathrm{C}$, at a speed of $6000 \mathrm{rpm}(\sim 3800 \mathrm{~g})$. The remaining pellet was discarded, and the supernatant was stored at $-80^{\circ} \mathrm{C}$ for further analysis. AChE activity was spectrophotometrically determined with a spectrophotometer multiplate Labsystem Multiskan EX, according to the methodology described by Ellman et al. (1961). AChE present in samples degrades acetylthiocholine (substrate), forming acetate and thiocholine. This degradation makes possible the consequent conjugation of thiocholine with DTNB [5,5'-dithiobis-(2-nitrobenzoic acid), also known as Ellmann's reagent] forming a yellow conjugate $\left(\varepsilon=1.36 \times 10^{4} \mathrm{M}^{-1} \mathrm{~cm}^{-1}\right)$. This allows quantifying cholinesterasic activity by assessing the absorbance increase at a wavelength of $412 \mathrm{~nm}$ (Nunes, 2011). AChE activity was expressed as $\mu$ moles of hydrolyzed substrate per minute, per mg of protein.

Liver and gill samples were homogenized in ice-cold phosphate buffer (50 mM, pH $=7.0,0.1 \%$ Triton X-100) and centrifuged at $4^{\circ} \mathrm{C}$ for $10 \mathrm{~min}$ at a speed of $15,000 \mathrm{~g}$. The obtained pellet was rejected and supernatants were recovered, divided into aliquots and frozen $\left(-80^{\circ} \mathrm{C}\right)$ for further analyses. CAT activity in liver was spectrophotometrically determined, by following the absorbance decrease correspondent to the decomposition of hydrogen peroxide to oxygen and water, during a time-course of $30 \mathrm{~s}$, at a wavelength of $240 \mathrm{~nm}\left(\varepsilon=0.00394 \pm 0.0002 \mathrm{mM}^{-1}\right.$ $\mathrm{mm}^{-1}$ ), according to the protocol by Aebi (1984). CAT activity was expressed in $\mu$ moles of $\mathrm{H}_{2} \mathrm{O}_{2}$ consumed per minute, per mg of protein.

GSTs activity was spectrophotometrically determined following the conjugation of the specific substrate CDNB (1-chloro-2,4dinitrobenzene) with GSH (glutathione, reduced form) forming a thioether whose formation can be accompanied at a wavelength of $340 \mathrm{~nm}\left(\varepsilon=9.6 \mathrm{mM}^{-1} \mathrm{~cm}^{-1}\right)$, following an adaptation from Habig et al. (1974). GSTs activities were quantified in gill and liver samples (see above), and were expressed in nanomoles of thioether produced per minute, per mg of protein.

Dorsal muscles samples were homogenized in ice-cold Tris/ $\mathrm{NaCl}$ buffer ( $\mathrm{pH}=7.2 ; 80 \mathrm{mM}$ Tris, $0.2 \mathrm{M} \mathrm{NaCl}$ ), and were subjected to three consecutive cycles of freezing and thawing, to force the rupture of the cellular membrane and release of intracellular content. Samples were then centrifuged at $4^{\circ} \mathrm{C}$, for $3 \mathrm{~min}$, at $6000 \mathrm{rpm}(\sim 3800 \mathrm{~g})$. The obtained pellet was discarded and subsequent testing was performed in the supernatant. LDH activity was spectrophotometrically determined by following the decrease of absorbance for a period of $5 \mathrm{~min}$, due to the simultaneous oxidation of NADPH and consumption of the substrate pyruvate by LDH (according to Vassault, 1983). This was followed at $340 \mathrm{~nm}$ $\left(\varepsilon=6.3 \mathrm{mM}^{-1} \mathrm{~cm}^{-1}\right)$, and activity was expressed as $\mu$ moles of hydrolyzed substrate per minute, per mg of protein.

Total soluble protein of all samples was determined using the Bradford method (Bradford, 1976), using gamma-globulin as a standard. All enzymatic activities (see above) were expressed as a function of the sample protein content.

\section{STATISTICAL ANALYSIS}

Two datasets were built: one with physiological and reproductive data (condition factors and indices) and the other with biomarker data. The overall profiles of both datasets were separately analyzed with Principal Component Analysis (PCA), which reduced the multidimensional data matrices to interpretable bidimensional plots that explained the highest proportion of variation in the data (following Ter Braak, 1995). Data were a priori centered and standardized to reduce scale effects (Ter Braak, 1995). TwoWay analyses of variance (ANOVA) were then performed on the PCA sample scores to assess seasonal (among months) and spatial (among sites) differences in the datasets. This allowed an overall appraisal of the sources of variation in the physiological and biochemical patterns of the studied populations. Similar approaches have been described in the literature for other reproductive and physiological data matrices (Loureiro et al., 2012; Correia et al., 2014b).

Because we were particularly interested in the biomarker profiles (see objectives), they were analyzed separately for each subpopulation. To encompass the observed seasonality, we defined discrete periods (feeding, reproduction, post-spawning) 
according to the seasonal profiles in physiological and reproductive condition. Thus, each of the enzymatic markers was analyzed with nested ANOVA-tests to assess the effect of period. Because each period comprised samples from different months, month was used as a fixed factor, nested within period (Quinn and Keough, 2002).

Additionally, we assessed the degree of association between the biomarker data and the physiological and reproductive status of the fish, using bivariate and multivariate approaches: (a) correlation analysis, and (b) redundancy analysis (RDA). In both cases, these approaches were applied to a global dataset (pooling the three subpopulations) and to reduced datasets for each subpopulation. Correlation analysis calculated the Pearson product moment coefficient $(r)$ for all combinations of enzymatic biomarkers and condition factors and indices. To reduce noise, we used a conservative approach and considered only correlations that cumulatively displayed high significance $(P \leq 0.01)$ and $r>0.3$ (i.e., moderate to strong association). RDA is a constrained ordination technique derived from PCA, and it was used to assess the amount of variation of the biomarker dataset that could be explained by the physiological and reproductive multivariate dataset. Monte Carlo permutation tests (unrestricted permutations) were used to assess the significance of the RDA models.

PCAs and RDAs were conducted with CANOCO for Windows version 4.5 (Scientia Ltd., Fulbourn, UK), whereas ANOVAs and graphs were carried out in Minitab 16 (Minitab Inc., State College PA, USA). A fixed level of significance was used $(P \leq 0.05)$, except where noticed.

\section{RESULTS}

\section{OVERALL PHYSIOLOGICAL AND BIOMARKER PROFILES - MULTIVARIATE ANALYSES}

A total of 380 animals were analyzed throughout 13 months, distributed by Aveiro $(n=130)$, Matosinhos $(n=120)$, and Peniche $(n=130)$ putative subpopulations. No fish were available at Matosinhos during February, since this period corresponded to the closed season. To assure some standardization in fish age and body size, captured fish were selected in order to maintain body length as uniform as possible (Aveiro: $19.1 \pm 1.97 \mathrm{~cm}$; Matosinhos: $18.7 \pm 1.56 \mathrm{~cm}$; mean length $\pm \mathrm{SD}$ ), although slightly larger fish were consistently captured in Peniche (20.9 \pm $0.90 \mathrm{~cm})$.

The initial exploration of the data, using PCA, revealed that variation in fish condition and reproductive state was mainly seasonal (see variance and F-test of ANOVA applied to PCA scores, Table 1), with only a minor contribution of site (see effect of site and month $\times$ site interaction, Table 1 ). The same was valid for the biomarker profile (Table 1). Indeed, the PCA biplots show a large scatter of fish scores (due to seasonality), but a high degree of overlap among subpopulations, both in terms of the condition and reproductive state (Figure 1A) and biomarker profile (Figure 1B). Only the first two PCA components were analyzed, as together they explained the largest fraction $(80.6 \%$ for fish condition and reproductive state and $62.5 \%$ for the biomarker profile) of the total variation of the data.

Redundancy analysis (RDA) revealed that the physiological and reproductive state of the fish could explain a significant portion (Monte Carlo permutation test, $P<0.05$ ) of the total variation of the biomarker data, for Aveiro (23.1\% of explained variation), Matosinhos (20\%), and Peniche (43.7\%) subpopulations. The proportion of variation explained in the Peniche subpopulation revealed a very high association of the two variable sets. When all data were pooled together, in a global RDA with the three subpopulations, fish condition and reproductive state explained $26.8 \%$ of the total variation of the biomarker data (significant RDA model: Monte Carlo permutation test, $P=0.002$ ). The portion of unexplained variation of the biomarker dataset is due to factors that were not measured, either endogenoussuch as sexual, age, and genetic differences (within and between subpopulations) - or exogenous (variations in temperature, food availability, contamination).

\section{FISH CONDITION AND REPRODUCTIVE STATE}

Condition factor $(\mathrm{K})$ of individuals of the three subpopulations monotonically increased throughout summer, which was accompanied by an increase in $\mathrm{K}_{\text {gut }}$ (Figure 2). During this period, the relative weight of liver ( $\mathrm{K}_{\text {liver }}$ and HSI) also increased (Figure 2).

Table 1 | Summary of Two-Way ANOVA on the fish scores (principal components 1 and 2), showing the degrees of freedom (d.f.), variance (MS), F-test and corresponding $P$-value.

\begin{tabular}{|c|c|c|c|c|c|c|c|c|c|}
\hline \multirow[t]{2}{*}{ Data } & \multirow[t]{2}{*}{ Source of variation } & \multicolumn{4}{|c|}{ Fish scores for PC1 } & \multicolumn{4}{|c|}{ Fish scores for PC2 } \\
\hline & & d.f. & MS & $\boldsymbol{F}$ & $\boldsymbol{P}$ & d.f. & MS & $\boldsymbol{F}$ & $\boldsymbol{P}$ \\
\hline \multirow[t]{4}{*}{ Condition and reproductive state } & Month & 11 & 20.0 & 127 & $<0.001$ & 11 & 6.48 & 35.1 & $<0.001$ \\
\hline & Site & 2 & 0.457 & 2.91 & 0.056 & 2 & 1.18 & 6.40 & 0.002 \\
\hline & Month $\times$ site & 22 & 1.10 & 7.00 & $<0.001$ & 22 & 1.08 & 5.83 & $<0.001$ \\
\hline & Residual & 324 & 0.157 & & & & 0.185 & & \\
\hline \multirow[t]{4}{*}{ Biomarker profile } & Month & 11 & 16.5 & 136 & $<0.001$ & 11 & 4.07 & 12.8 & $<0.001$ \\
\hline & Site & 2 & 4.91 & 40.6 & $<0.001$ & 2 & 1.09 & 6.00 & 0.003 \\
\hline & Month $\times$ site & 22 & 0.713 & 5.88 & $<0.001$ & 22 & 1.04 & 3.27 & $<0.001$ \\
\hline & Residual & 324 & 0.121 & & & 324 & 0.318 & & \\
\hline
\end{tabular}

February scores were excluded from the analysis due to the absence of data from Matosinhos subpopulation. 

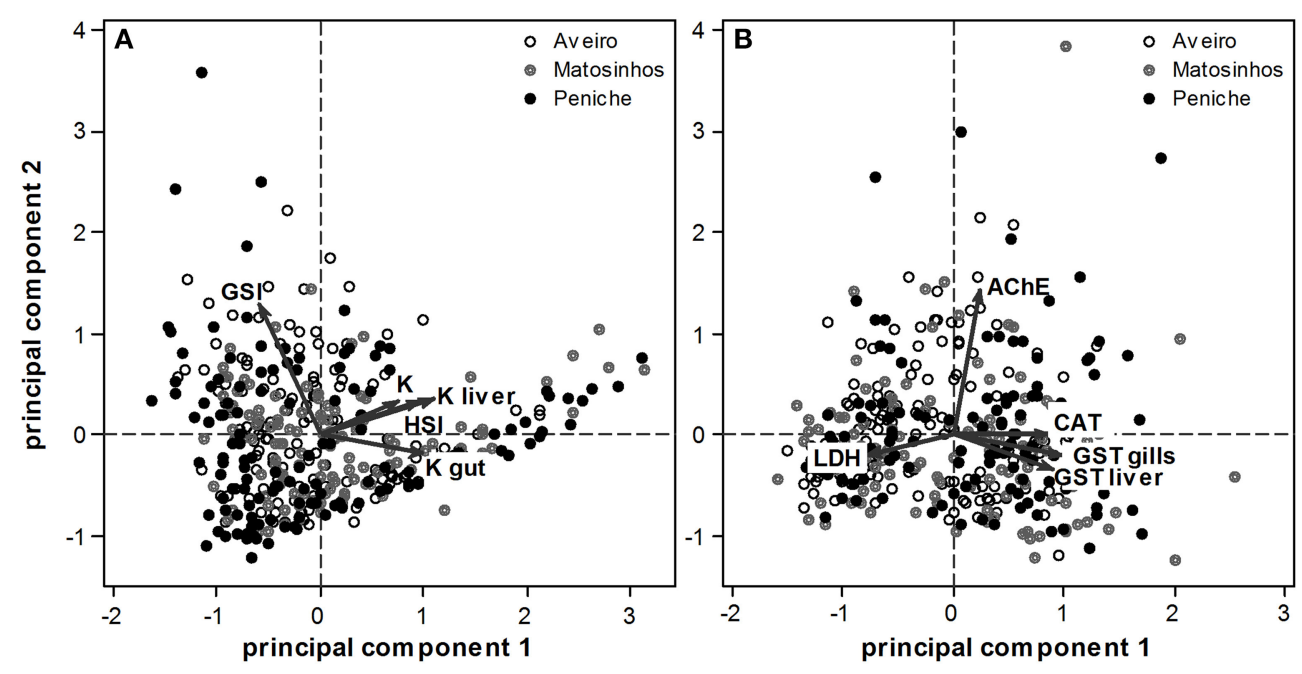

FIGURE 1 | PCA biplots of fish scores of three subpopulations of Sardina pilchardus (Aveiro, Matosinhos and Peniche), illustrating their variation according to physiological (condition) and reproductive state (A) and

biomarker profile (B). Dots depict individual fish (from different subpopulations) and arrows represent physiological and biochemical gradients.

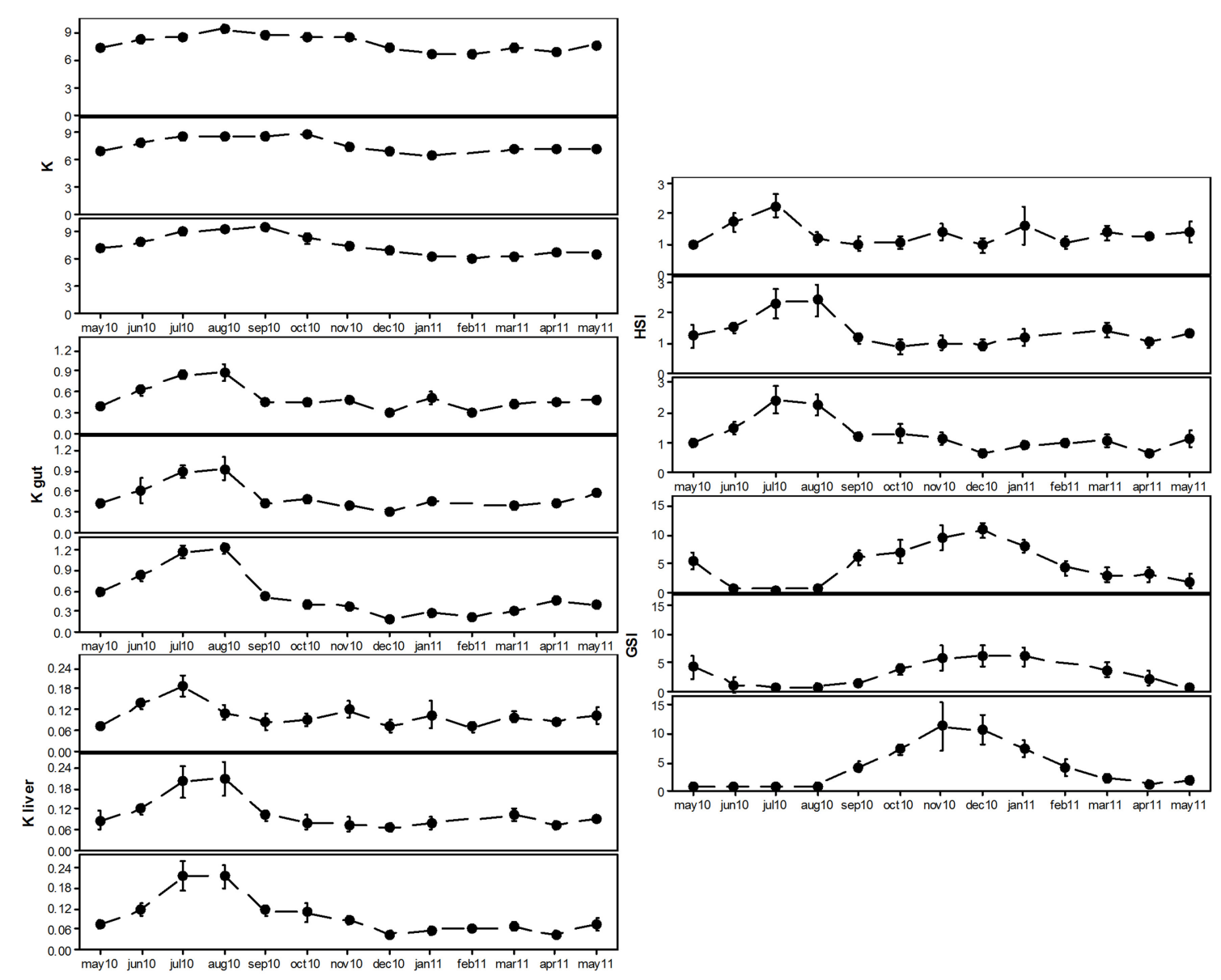

FIGURE 2 | Monthly variation of condition factors ( $K, K_{\text {gut }}$, and $\mathrm{K}_{\text {liver }}$ ), hepatosomatic index (HSI) and gonadosomatic index (GSI) of three subpopulations of Sardina pilchardus (Aveiro, top panel; Matosinhos, middle panel; and Peniche, bottom panel). Error bars represent $95 \%$ confidence intervals $(n=10$ in each month). 
This is characteristic of a feeding period, accompanied by the storage of energy reserves in the liver (June-August). From September onwards, feeding decreased (see abrupt fall of $\mathrm{K}_{\text {gut }}$ ) and liver condition also dropped. Concomitantly, condition of fish decreased. During this period, GSI increased in all subpopulations, reaching its maximum in November or December (Figure 2). This suggests a period of gametogenesis, which was consistent among subpopulations, although less pronounced in Matosinhos subpopulation. From December onwards, GSI dropped, which is consistent with gamete release (spawning). Condition remained low throughout this period. Condition and reproductive state were clearly associated: GSI and HSI were inversely associated ( $r=-0.300 ; P<0.001)$, for all sampling sites; GSI was also inversely related to liver condition $\left(\mathrm{K}_{\text {liver }} ; r=-0.320 ; P<0.001\right)$ and gut fullness $\left(\mathrm{K}_{\mathrm{gut}} ; r=-0.509 ; P<0.001\right)$. This resulted in consistent seasonal patterns, and only minor differences were observed among subpopulations (e.g., lower liver condition in August for Aveiro subpopulation). This strong seasonal pattern confirms the above analysis (ANOVA on PCA scores), which shows a large seasonal component and only a minor contribution of among-subpopulation variation. Thus, three distinct periods were found in all three subpopulations, reflecting the physiological and reproductive cycle: (a) feeding and energy storage (June-August); (b) reproduction - gametogenesis and spawning (September-January); (c) post-spawning (February-May).

This distinction between periods is visible in the overall physiological and reproductive profile of the three subpopulations (Figure 3 top panel). The feeding (June-August) and reproduction (September-January) period are clearly separated, while the post-spawning period (February-May) occupies an intermediate position. This is related to the increased condition during the feeding period and increased GSI during the reproduction period (see arrows in Figure 1A). Again, albeit small differences, the pattern is still consistent in all three subpopulations.

\section{BIOMARKER DATA}

The distinction between periods (see above) is visible in the overall biomarker profile of the three subpopulations (Figure 3

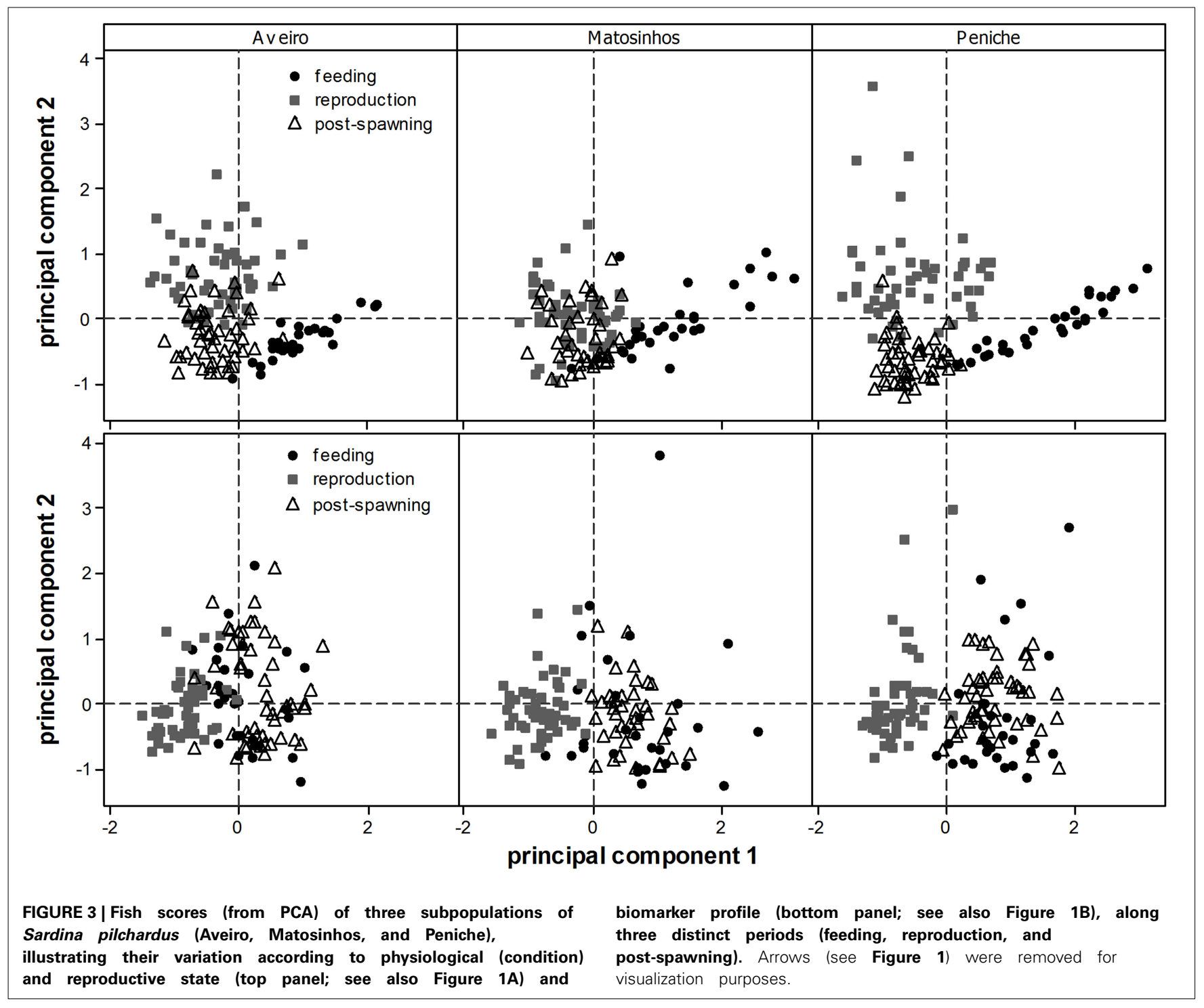


bottom panel). The reproduction period is clearly separated from the remaining periods, which is mostly related to gradients in LDH, CAT and GSTs activities (see arrows in Figure 1B). Small differences among sites are visible but this general pattern is fairly consistent in all three subpopulations.

Variability of enzymatic biomarkers was clearly related to the physiological and reproductive state of the fish, as a significant effect of period (feeding, reproduction and post-spawning) was observed in almost all cases (Table 2). The exception was AChE, which remained unaltered throughout the sampling period, except for Aveiro individuals. However, even in this case, the differences were not very pronounced.

The activity of LDH in the muscle of S. pilchardus was generally consistent in all sampling sites, and increased progressively from May to September, and then suffered a significant decrease until January. All other biomarkers varied substantially across periods and a consistent pattern clearly emerged (Figure 4): during the reproductive period (allocation of energy reserves to gametogenesis + spawning), CAT and GSTs activities were significantly lower; during non-reproductive periods, the levels of these two biomarkers were significantly increased.

\section{BIOMARKERS DEPEND ON FISH CONDITION}

The coupling of physiological $\times$ reproductive state and biochemical markers (see above) is also clear when looking at correlations between the two sets of variables. These correlations were observed in a global dataset, including all putative subpopulations; however, they were also significant in reduced datasets for each of the three subpopulations. Negatively significant correlations were found between reproductive state (GSI) and CAT $(r=-0.430 ; P<0.001), \mathrm{GST}_{\text {liver }}(r=-0.443: P<0.001)$ and $\mathrm{GST}_{\text {gills }}(r=-0.456 ; P<0.001)$ activities. This clearly corroborates the lower activities consistently observed during the reproductive period, and for animals of all three sampling sites (see

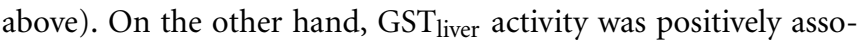
ciated with liver condition, measured as $\mathrm{K}_{\text {liver }}(r=0.384 ; P<$ $0.001)$ and HSI $(r=0.377 ; P<0.001)$, as well as with stomach condition, $\mathrm{K}_{\text {gut }}(r=0.464 ; P<0.001)$. Last, LDH muscle activity was significantly correlated with overall condition, $\mathrm{K}(r=0.555$; $P<0.001)$.

\section{DISCUSSION}

The here-obtained data corroborate the conclusions drawn by Chícharo (1998) and Nunes et al. (2011), who established that S. pilchardus from the coastal waters of Portugal were reproductively active from autumn to spring. As a consequence, this organism shows a large effect of seasonality in terms of its body composition and physiological state: it accumulates fat in the gut, muscles and under the skin, and there are seasonal and spatial differences in the amount of stored fatty acids (Garrido et al., 2007). During November and December, it was possible to observe a significant increase in GSI, reflecting the onset of the winter spawning season; this period was preceded by an intense nutrient uptake and accumulation of energetic reserves from June to September, reflected by considerable rises in HSI and $\mathrm{K}$. These findings are in agreement with those of Nunes et al. (2011), who found a seasonal transition from a period of energy allocation to reproduction (autumn and winter) to a period of resource allocation into growth and fat deposition (spring and summer). The spawning season is responsible for the

Table 2 | Summary of nested ANOVA on biomarker data across periods (feeding, reproduction, post-spawning), showing the degrees of freedom (d.f.), variance (MS), $F$-test and corresponding $P$-value.

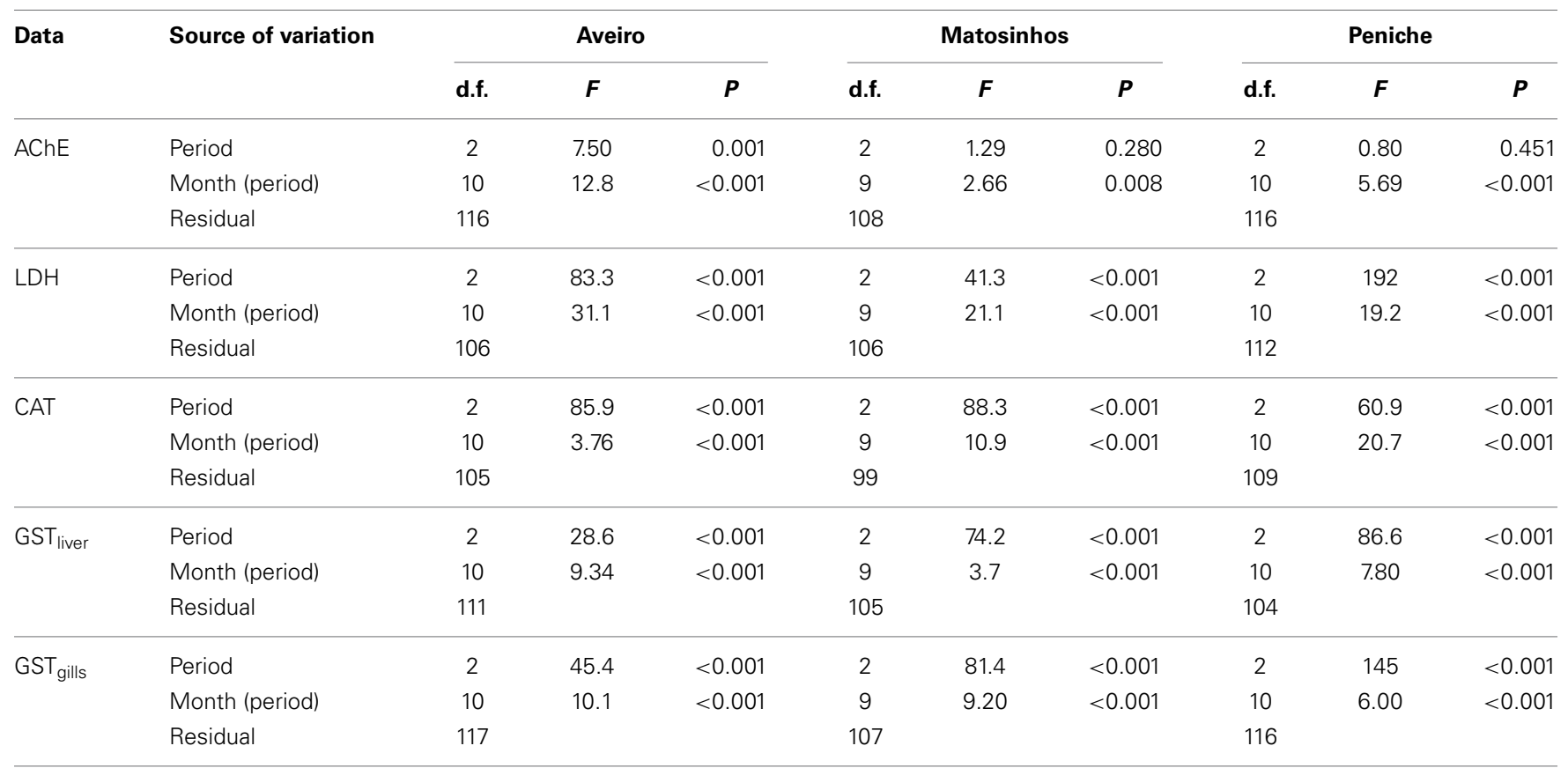

All factors are fixed. 


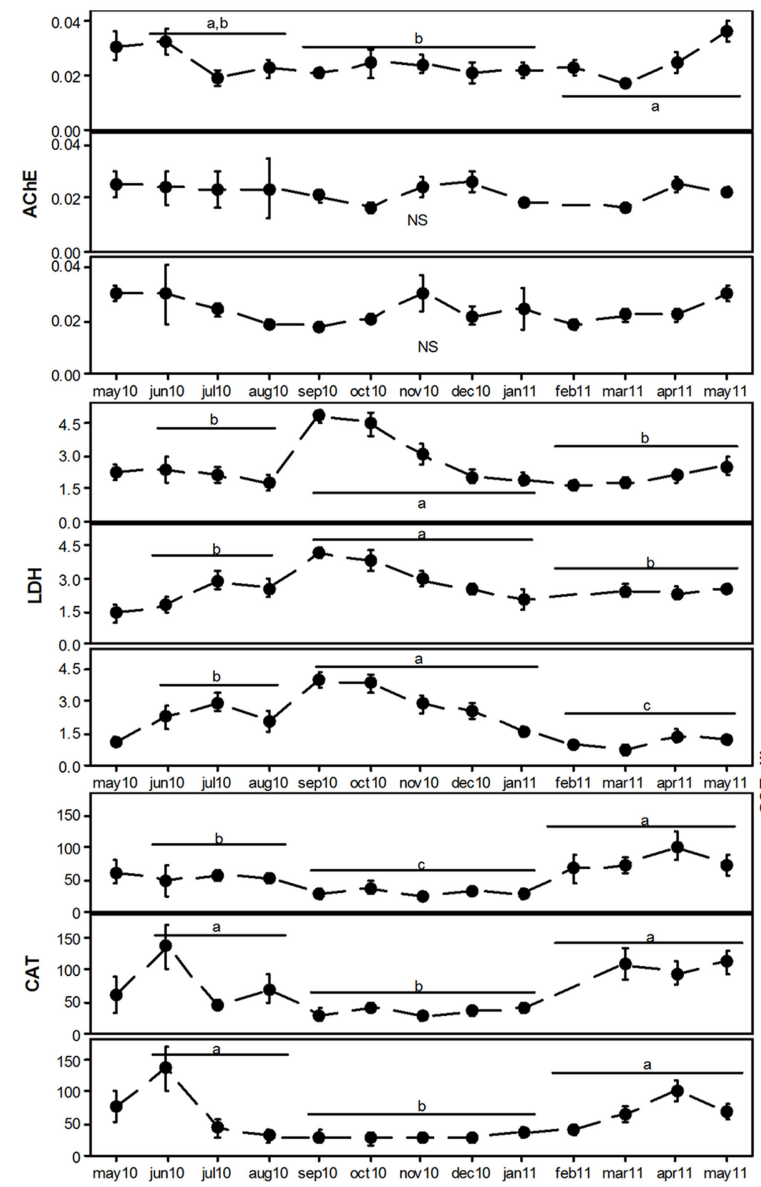

FIGURE 4 | Monthly variation in AChE, LDH, CAT and GSTs of three subpopulations of Sardina pilchardus (Aveiro, top panel; Matosinhos, middle panel; and Peniche, bottom panel). Error bars represent $95 \%$ confidence intervals $(n=10$

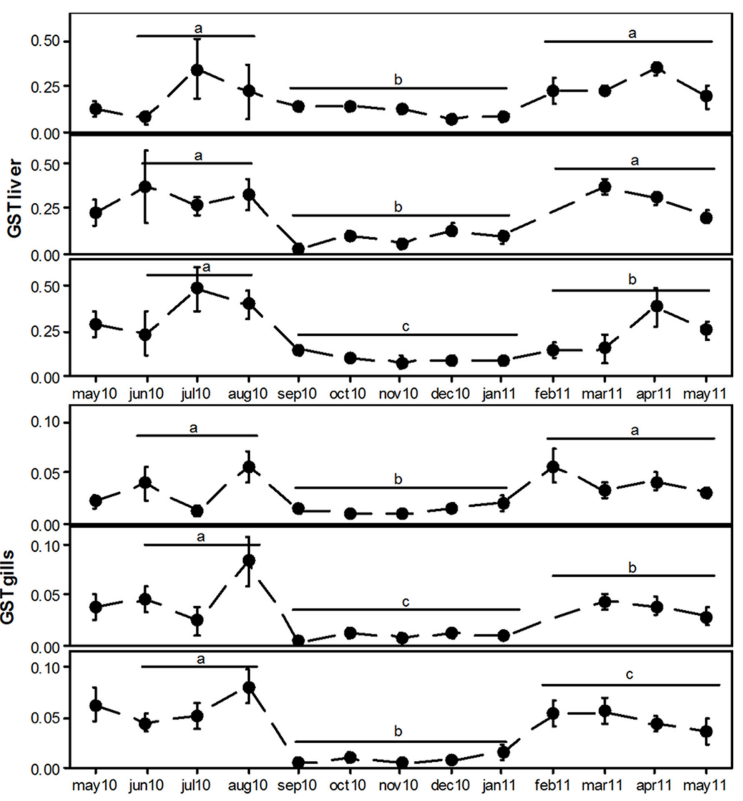

in each month). Different lowercase letters represent significant differences of the measured variable among feeding (JuneAugust), reproduction (September-January) and post-spawning (February-May) periods. mobilization of high-energy reserves, mainly obtained by conversion of lipids previously accumulated, or resulting from feeding during the spawning period (Garrido et al., 2008; Nunes et al., 2011). Immediately after the spawning season (with a strong reduction of the GSI), it is possible to observe a distinct period, known as ovary resting phase, during which the fish improves its condition (Kleinkauf et al., 2004; Nunes et al., 2011). Availability of nutrients during this phase is critical, since it conditions the amount of fat reserves that are accumulated before the spawning season, thus influencing reproduction (Garrido et al., 2008). Seasonal variations in the amount of fat in tissues of $S$. pilchardus are a result of their location during the spawning season, and the maturation status of gonadal tissue can be related to the seasonality of the diet, and to the water temperature (Garrido et al., 2008; Ganias, 2009). According to Chícharo (1998), spawning is modulated by water temperature, and only occurs at temperatures between 14 and $16^{\circ} \mathrm{C}$; this may explain the differences observed among the three sampling sites, in terms of the quantified indexes.

Fish liver is an important temporary storage organ of lipids and glycogen, whose size may increase immediately before the spawning season (Kleinkauf et al., 2004; Nunes et al., 2011; Trujillo-Jiménez et al., 2011). Lipids are, together with proteins, the main organic chemical constituents of fishes (Tocher, 2003). The role of fatty acids is particularly important in energy metabolism, under the form of ATP, which is the basis for growth, reproduction, and migration. It is possible to suggest that the amount of stored fatty acids must assure the energy needs of both parental fish and of their offspring (Tocher, 2003). The low values of HSI, before and after spawning, may result from the transference of energetic reserves from the liver to the gonads, to allow the occurrence of reproductive events (Trujillo-Jiménez et al., 2011). After gametogenesis and spawning, reserve substances in the liver suffered a drastic reduction, leading to the reduction of liver weight and, consequently, of the indexes of hepatic condition, including HSI and $\mathrm{K}_{\text {liver }}$ (Kleinkauf et al., 2004; Trujillo-Jiménez et al., 2011). Our results showed that the hepatic reserves were clearly associated to GSI, in part because spawning and feeding are also associated, as earlier mentioned. Increases in GSI were observed immediately after a period of high availability of food (Jul-Aug), which was demonstrated by a sharp increase in $\mathrm{K}_{\text {gut }}$. 
This corroborates the data obtained by Coelho (2002), which showed that the strongest feeding period of sardines typically occurs from July to September, due to the upwelling phenomena that favors high densities of phyto- and zooplankton. Sardines feed intensively during the reproductive resting phase; however, during spawning sardines can also feed, but nutrients are mobilized for the gonadal tissue, not being accumulated (Garrido et al., 2008). Our results for all analyzed subpopulations are in line with previously published data, showing that the reproductive activity varied inversely in relation to the somatic condition and fat accumulation, which occurred mainly during Summer (Silva et al., 2006; Ganias, 2009; Nunes et al., 2011). These seasonal changes had implications in the enzymatic profiles of the selected biomarkers.

The variability concerning biomarker data is very much related to the observed reproductive and physiological changes throughout the sampling period. In addition to pollution, several other factors may bias biological responses that are used as biomarkers. Among these, health condition, sex, age, nutritional status/food availability, reproductive phase, metabolic activity, population density, migratory behavior, and environmental factors (e.g., season, and temperature) can alter the physiology of test organisms, thus compromising the effectiveness of biomarker use in environmental analysis, namely for the detection of contamination (van der Oost et al., 2003; Napierska et al., 2009). Additionally, all the mentioned factors can even alter the bioaccumulation profiles and the levels of pollutants in tissues of exposed organisms (Stanic et al., 2006; Vidal-Liñán et al., 2010). It is possible to sustain that modifications in biomarker levels can also be due to the natural physiological cycles of sampled organisms, rather than being indicators of exposure to chemical pollution (Sheehan and Power, 1999; Vidal-Liñán et al., 2010). Indeed, the distinction between periods (which were defined according to the physiological and reproductive state) is visible in the overall biomarker profile of the three subpopulations. The reproduction period is clearly separated from the remaining periods, which is mostly related to gradients in LDH, CAT and GSTs activities. AChE, on the other hand, remained fairly unaltered throughout the sampling period, except for Aveiro individuals. This is not surprising, since cholinesterases present in the nervous system are usually constitutively expressed, and their increase occurs under strict physiological control. On the other hand, and given the absence of significant depressive effects, it is possible to assume the lack of compounds with anticholinesterasic effects (e.g., pesticides of agricultural use) to which sardines could have been exposed (Nunes, 2011). The presence of significant levels of anticholinesterasics in open oceanic waters is not common, and the presence of such residues is mainly explained by atmospheric deposition (Mai et al., 2013). However, the co-occurrence of diffuse pollution, including metals, tensioactive compounds and, most important, hydrocarbons could alter cholinesterasic activity of fish (Akaishi et al., 2004); however, this did not occur, suggesting the absence of cholinesterase inhibitors in the area. The lack of significant fluctuations of AChE activity throughout the year contrasts with some studies, which had suggested the possibility of modifications in AChE activity as a result of seasonal variations (Vidal et al., 2002; Lau et al., 2004; Leiniö and Lehtonen,
2005; Bocchetti et al., 2008); temperature, for example, is one of the most prominent factors affecting acetylcholinesterasic activity (Leiniö and Lehtonen, 2005). Our data do not support the latter argument as no objective patterns along the year were devised.

The activity of LDH in the muscle of S. pilchardus was generally consistent, increasing progressively during the feeding and storage period, and then suffering a significant decrease during spawning. It is possible to hypothesize that $\mathrm{LDH}$ increase may reflect a response to augmented energy demands, during anabolism and energy allocation to reproductive processes. Spawning in fish is an extremely demanding process in terms of energy production and allocation, which in turn depend upon the availability of nutrients (namely protein and energetic nutrients from the diet), as shown by Abdel-Fattah and Kawanna (2008). Considering the pelagic nature of S. pilchardus, and its need to be continuously in motion for vast distances, it is likely that LDH was overexpressed as a response to the allocation of nutrients previous to the spawning effort, thus privileging the anaerobic pathway of energy synthesis. Therefore, the increase of LDH coincided with the physiological phase of allocation of energy reserves to gametogenesis, for subsequent spawning, reflecting the use of an anaerobic alternative pathway for obtaining energy during this critical phase, as already suggested by Chatzifotis et al. (2011). Having to cope with increase energetic requirements, fish muscle tended to increase the portion of energy obtained from anaerobic processes. Concomitantly, the increase in LDH activity may also have been related to the increase of temperature along the year. Temperature is one of the main variables that conditions the level of dissolved oxygen in water; lower levels of oxygen can in turn cause increases in anaerobic metabolism in aquatic organisms (namely, fish), which are elicited by significant rises in LDH activity in highly demanding tissues, such as muscle (Thébault, 1984; Wu and Lam, 1997; Nathan et al., 2006). LDH is responsible for the continuation of glycolysis under hypoxic conditions, which is the main justification of its use for the assessment of the metabolic state of the organism (Moreira et al., 2006). The hereobtained results (increase of LDH activity during hotter months, late spring and summer) may thus reflect the increase in water temperature and consequent decrease in oxygen concentration. Additionally, fish can alter their preferential metabolic pathway, changing from aerobic to anaerobic according to the rise in water temperature, as shown by Nilsson et al. (2009). This may explain the here-obtained results regarding the fluctuation of LDH levels.

CAT and GSTs activities were significantly lower during the reproductive period, whilst the levels of these two biomarkers (which are clearly oxidative-related) were significantly increased during non-reproductive periods. This may be explained by the nature of the aerobic metabolism required for anabolism, and also for the biosynthesis of energetic reserves, which are to be mobilized to gametogenesis and incorporated into the gametes, prior to spawning. Considering that both enzymes had their activities significantly induced during warmer periods, which coincided with anabolism/biosynthesis of reserves, it is possible to sustain the occurrence of conditions more favorable to oxidative stress. This is a pattern already demonstrated for other marine fish species, including Zoarces viviparous (Heise et al., 2007), Solea senegalensis (Oliva et al., 2012), and Mugil cephalus (Padmini 
and Vijaya Geetha, 2009). The discussion of both biomarkers is intrinsically connected, since CAT and GSTs may give further insights into physiological oxidative processes. Both CAT and GSTs activities were substantially higher during May and June. Several studies show that CAT activity in marine organisms may be modulated by seasonal variations, including reproductive cycles and nutritional status (Regoli, 1998; Sheehan and Power, 1999; Vidal et al., 2002; Leiniö and Lehtonen, 2005; Vidal-Liñán et al., 2010). Catalase is mainly located in a specific intracellular organelle of the liver, the peroxisome, whose function is related to metabolism of fatty acids (Huggett et al., 1992), with release of $\mathrm{H}_{2} \mathrm{O}_{2}$ as by-product. Hydrogen peroxide is an oxidant compound, and consequently toxic to the cell, and thus the catalytic activity of CAT is required for its dismutation (Huggett et al., 1992). It is licit to suggest that, during a period of large food availability (such as May-June), aerobic metabolism is intensified for an increased nutrient absorption, leading to the formation and release of oxyradicals during catabolism of ingested substances. This increased metabolic rate can ultimately cause an increase in CAT activity (Regoli, 1998; Vidal et al., 2002; Leiniö and Lehtonen, 2005), which is in agreement with the hereobtained data. Temperature increase per se can stimulate the global metabolic processes, favoring a transient overproduction of ROS, resulting in pro-oxidative conditions (Lushchak, 2011). Data published by Vinagre et al. (2012) corroborated the role of temperature on the increased levels of CAT measured in the marine fish species Dicentrarchus labrax. According to this study, higher water temperatures can lead to a significant (almost sevenfold) increase in CAT activity. Catalase increase was also followed by lipid peroxidation, showing a well-established linkage between high temperature and the onset of oxidative stress-related processes in fish. On the other hand, CAT activity followed a descending pattern, for specific time periods. As described by Pavlović et al. (2010), reduction of CAT activity may occur as a consequence of low temperature, but also to shortage of nutrients and/or gonad maturation.

A similar pattern was observed for GSTs activities along the year, and for all sampling stations. Besides being biotransformation enzymes (namely, of phase II or conjugation), GSTs activity is also noteworthy in scenarios of oxidative stress. It is thus possible to suggest that the underlying mechanisms justifying the adopted rationale for the discussion of CAT data can be adopted as well: increase of metabolism and oxygen consumption, resulting from increased food intake, can favor the overproduction of ROS; these intermediates can be promptly scavenged by conjugation with glutathione, a step that occurs with the mandatory intervention of GSTs. A rise in ROS can lead to a significant enhancement of GSTs activity, a phenomenon that was clearly observed (for both gills and liver) for the period comprised from May to August. Despite this generic tendency, this pattern was not absolutely noticeable for animals landed in Aveiro. During the period Sept-Jan, GSTs activity dropped dramatically, for the three sampling sites, suggesting that low temperatures can reduce metabolic activity, ROS production, and ultimately, GSTs expression and activity. The work published by Manduzio et al. (2004) showed that higher temperature and increased availability of nutrients induce the consumption of oxygen and the generation of ROS, which is compensated by the increase of the antioxidant defense system efficacy. Again, seasonality seems to play a decisive role concerning GSTs metabolism, as already postulated by several authors (Regoli, 1998; Kaaya et al., 1999; Vidal et al., 2002; Manduzio et al., 2004; Leiniö and Lehtonen, 2005). High values of GSTs activity appear to coincide with the reestablishment of nutrient reserves and periods of gametogenesis; low periods of GSTs seem to be associated to spawning periods (Kaaya et al., 1999). Indeed, GST in the liver was positively associated with lower condition and stomach fullness, reflecting the influence of a higher intake of food, and consequent increase in the metabolic rate in liver tissue. Under conditions of increased metabolic activity, one may expect a rise in the production of electrophilic compounds resulting from metabolism, which require the activation of GSTs to be properly metabolized and promptly excreted (Wang and Ballatori, 1998).

The geographical distance between the three sampling areas did not produce a significant distinction in any of the biological indicators (physiological and reproductive state, and biomarkers). Indeed, all selected indicators fluctuated roughly under a similar pattern, clearly related to natural variation. This supports the idea of genetic resemblance among subpopulations, an idea corroborated by Castro (2007) and Correia et al. (2014a), whose analysis of otolith elemental fingerprints evidenced the existence of a single northern recruitment area in the Atlantic Ocean for this species.

Marine ecosystems are the final receptors of an immense set of pollutants, and several biomonitoring programs have already been developed and implemented in the Atlantic area (Stagg, 1998; Roose and Brinkman, 2005). The use of biomarker data for detecting pollutant exposure is an old idea (Peakall, 1992; Heath, 1995), but the recognition of natural variability (seasonal and spatial, for example) is the first step toward the need of setting up baseline values for biomonitoring programs. Natural variability is often deliberately eliminated from the majority of studies, namely those that are strictly laboratory-based; however, variability is a natural and desirable phenomenon that must be considered, and whose effects must be accounted for, especially in biomonitoring studies developed with assessments of the most diverse end-points on wild species. Acknowledging and assessing these natural sources of variation will greatly contribute to reduce uncertainties when performing multi-scale assessments of ecosystem quality, which is the main advantage of the here-proposed biochemical and physiological approach. Our data clearly show that the ecological knowledge of the studied species is useful in defining sampling periods and baseline levels, and there is a critical need to complement biomarker data with quantifiable indices of reproductive, nutrition, and overall physiological status. In our study, only AChE was sufficiently consistent throughout the sampling period, whilst other biomarkers are strongly dependent on the physiological and reproductive condition of the fish. This must be acknowledged if these markers are to be integrated in biomonitoring studies of coastal pollution. This is particularly important because the documented contamination of the Atlantic Ocean mainly occurs by a diffuse set of substances, which brings additional uncertainty as a result of the complexity of potentially noxious chemical agents. These include microplastics (Cole 
et al., 2011), pesticides, industrial chemicals, organobromine compounds (Weigel et al., 2005), chlorobiphenyls and PAHs (Schulz-Bull et al., 1998; Nizzetto et al., 2008), resulting from dissolution of chemicals dissolved in the upper layer of oceanic water (Wurl and Obbard, 2004). Some of these compounds, namely PCBs and organochlorine pesticides, can be absorbed and bioaccumulate in fish inhabiting the upper water layers (Froescheis et al., 2000; Looser et al., 2000), such as sardines. Also, recent concerns have arisen from the potential impact of the large amount of small debris that occur in the pelagic system and that are entering the trophic webs; emergent pollutants, such as micronized plastics (Wright et al., 2013; Ivar do Sul and Costa, 2014), can be ingested by filter-feeding organisms and cause endocrine disruption, oxidative stress, among others. Despite occurring in extremely low levels, the effects of such compounds can be measured by means of quantifying the biological response (and its extent) elicited in exposed organisms using biomarkers (Timbrell, 1998; Cajaraville et al., 2000). This study established a first step toward the potential definition of sampling periods for a biomonitoring program with an ubiquitous fish resource in the northern Atlantic, whose capture is warranted by the commercial fleets, and clearly demonstrated the importance of taking into consideration the internal drivers of population dynamics and physiological condition within a multi-scale approach for the assessment of ecosystem quality.

\section{CONCLUSIONS}

The obtained data are of particular importance in terms of future biomonitoring programs: it was possible to successfully address a set of practical, logistical issues, which included the establishment of a sampling strategy dependent upon commercial vessels of the Portuguese coastal traditional fishing fleet, and the calculation of baseline values for all tested biomarkers. Additionally, and given the agreement of the generic trends in the annual variation of biomarkers among all sampling sites, it is possible to confirm a consistent spatial pattern along the Portuguese coast for the S. pilchardus metapopulation. Despite the geographical dispersion of proveniences, tendencies of body indexes and biomarkers values were noticeably similar. On the one hand, if specific spots of oceanic contamination were hypothetically present in any of the sampled areas, it seems likely that differences among all sampled locations should have been reported; on the other hand, these data support the potential of $S$. pilchardus populations as a bioindicator species, especially if biomarker data can be conjugated with chemical analyses for contaminant body burdens.

The main conclusion to be drawn from this entire set of data involves the recognition that seasonal variations are the uttermost important factors to address in biomonitoring programs. Considering the extent of the fluctuations in biological responses along the year, the interdependence of all analyzed criteria, and the physiological effects that are likely to occur and act as confounding factors for the ulterior interpretation of data, it is mandatory to fully characterize the trinomial combination (1) the particular species to be used in the biomonitoring program; (2) biotic/abiotic conditions (including contamination profiles) to which the species are to be exposed and that can be held responsible for eliciting responses; (3) time course of the sampling period (acute/chronic and the quali-quantitative differences that may result. Only with full knowledge of the chemicalbiological interactions it will be possible to understand the nature, typology and likely occurrence of toxic effects in the marine ecosystem.

\section{ACKNOWLEDGMENTS}

This work was supported by European Funds through COMPETE and by National Funds through the Portuguese Science Foundation (FCT) within project PEst-C/MAR/LA0017/2013. This work was also partially funded by FCT via the project BiOtoMetal (PTDC/AMB/70431/2006). Bruno B. Castro is hired under the program Ciência 2008 (FCT, Portugal), co-funded by the Human Potential Operational Programme (National Strategic Reference Framework 2007-2013) and European Social Fund (EU). None of the funding sources had any contribution for the experimental design adopted. The authors would also like to thank the valuable contribution of DOCAPESCA, Portos e Lotas, SA, which granted us access to the commercial fishing fleets at Matosinhos, Aveiro and Peniche harbors.

$\mathrm{BN}$ conceived the rationale and the experimental design for the study, which was discussed with BC and FG. RT conducted the practical execution of the work under the direct supervision of BN and $\mathrm{BC}$, within the research group coordinated by FG. Collection of specimens was carried out by $\mathrm{RT}, \mathrm{BN}$ and $\mathrm{BC}$, and the travel expenses were supported by FG and project Bio(To)Metal (lead by $\mathrm{BN}$ ). FG also contributed with chemicals, reagents, materials, equipments, and lab space. BC carried out the statistical analysis of the data, and all authors participated in the various discussions about the results. BN, RT and BC wrote the paper, and FG provided a critical revision of the manuscript.

\section{REFERENCES}

Abdel-Fattah, M. E.-S., and Kawanna, M. (2008). Effects of dietary protein and energy levels on spawning performance of Nile tilapia (Oreochromis niloticus) broodstock in a recycling system. Aquaculture 280, 179-184. doi: 10.1016/j.aquaculture.2008.04.030

Aebi, H. (1984). Catalase in vitro. Methods Enzymol. 6, 105-121.

Akaishi, F. M., de Assis, H. C., Jakobi, S. C., Eiras-Stofella, D. R., St-Jean, S. D., Courtenay, S. C., et al. (2004). Morphological and neurotoxicological findings in tropical freshwater fish (Astyanax sp.) after waterborne and acute exposure to water soluble fraction (WSF) of crude oil. Arch. Environ. Contam. Toxicol. 46, 244-253. doi: 10.1007/s00244-003-2260-1

Amado, J., Antunes, P., Gil, O., and Vale, C. (2006). Mobility of organochlorines in muscle of sardine (Sardina pilchardus) during spawning in the Portuguese coast. Ciencias Mar. 32, 369-377. doi: 10.7773/cm.v32i22.1095

Amenzoui, K., Ferhan-Tachinante, F., Yahyaoui, A., Kifani, S., and Mesfioui, A. H. (2006). Analysis of the cycle of reproduction of Sardina pilchardus (Walbaum, 1792) off the Moroccan Atlantic coast. C. R. Biol. 329, 892-901. doi: 10.1016/j.crvi.2006.08.002

Antunes, P., Amado, J., Vale, C., and Gil, O. (2007). Influence of the chemical structure on mobility of PCB congeners in female and male sardine (Sardina pilchardus) from Portuguese coast. Chemosphere 69, 395-402. doi: 10.1016/j.chemosphere.2007.04.084

Antunes, S. C., Marques, S. M., Pereira, R., Gonçalves, F., and Nunes, B. (2010). Testing procedures for the determination of several biomarkers in different species, for environmental assessment of pollution. J. Environ. Monit. 12, 1625-1630. doi: 10.1039/b926647j

Bocchetti, R., Lamberti, C. V., Pisanelli, B., Razzetti, E. M., Maggi, C., Catalano, B., et al. (2008). Seasonal variations of exposure biomarkers, oxidative stress responses and cell damage in the clams, Tapes philippinarum, and mussels, 
Mytilus galloprovincialis, from Adriatic sea. Mar. Environ. Res. 66, 24-26. doi: 10.1016/i.marenvres.2008.02.013

Bradford, M. M. (1976). A rapid and sensitive method for the quantitation of microgram quantities of protein utilizing the principle of proteindye binding. Anal. Biochem. 72, 248-254. doi: 10.1016/0003-2697(76) 90527-3

Cabañero, A. I., Carvalho, C., Madrid, Y., Batoréu, C., and Cámara, C. (2005). Quantification and speciation of mercury and selenium in fish samples of high consumption in Spain and Portugal. Biol. Trace Elem. Res. 103, 17-35. doi: 10.1385/BTER:103:1:017

Cajaraville, M. P., Bebianno, M. J., Blasco, J., Porte, C., Sarasquete, C., and Viarengo, A. (2000). The use of biomarkers to assess the impact of pollution in coastal environments of the Iberian Peninsula: a practical approach. Sci. Total Environ. 247, 295-311. doi: 10.1016/S0048-9697(99)00499-4

Canli, M., and Atli, G. (2003). The relationships between heavy metal (Cd, Cr, Cu, $\mathrm{Fe}, \mathrm{Pb}, \mathrm{Zn}$ ) levels and the size of six Mediterranean fish species. Environ. Pollut. 121, 129-136. doi: 10.1016/S0269-7491(02)00194-X

Castro, B. G. (2007). Element composition of sardine (Sardina pilchardus) otoliths along the Atlantic Coast of the Iberian Peninsula. ICES J. Mar. Sci. 64, 512-518. doi: 10.1093 /icesjms/fsm017

Chatzifotis, S., Papadaki, M., Despoti, S., Roufidou, C., and Antonopoulou, E. (2011). Effect of starvation and re-feeding on reproductive indices, body weight, plasma metabolites and oxidative enzymes of sea bass (Dicentrarchus labrax). Aquaculture 316, 53-59. doi: 10.1016/j.aquaculture.2011.02.044

Chícharo, M. A. (1998). Nutritional condition and starvation in Sardina pilchardus (L.) larvae off southern Portugal compared with some environmental factors. J. Exp. Mar. Bio. Ecol. 225, 123-137. doi: 10.1016/S0022-0981(97) 00212-8

Chi, Z., Liu, R., and Zhang, H. (2010). Potential enzyme toxicity of oxytetracycline to catalase. Sci. Total Environ. 408, 5399-5404. doi: 10.1016/j.scitotenv. 2010.08.005

Coelho, C. S. F. G. (2002). Alimentação de Sardina pilchardus (Walbaum, 1792) ao largo da costa continental portuguesa e implicações da condição nutricional das fêmeas na qualidade dos oócitos. M.Sc. thesis, Institute of Biomedical Sciences Abel Salavar, University of Porto, Oporto. Available online at: http://repositorioaberto.up.pt/handle/10216/9823

Cole, M., Lindeque, P., Halsband, C., and Galloway, T. S. (2011). Microplastics as contaminants in the marine environment: a review. Mar. Pollut. Bull. 62, 2588-2597. doi: 10.1016/j.marpolbul.2011.09.025

Contestabile, A., and Zannoni, N. (1975). Histochemical localization of acetylcholinesterase in the cerebellum and optic tectum of four freshwater teleosts. Histochemistry 45, 279-288. doi: 10.1007/BF00492630

Correia, A. T., Hamer, P., Carocinho, B., and Silva, A. (2014a). Evidence for metapopulation structure of Sardina pilchardus in the Atlantic Iberian waters from otolith elemental signatures of a strong cohort. Fish. Res. 149, 76-85. doi: 10.1016/j.fishres.2013.09.016

Correia, B., Pintó-Marijuan, M., Neves, L., Brossa, R., Dias, M. C., Costa, A., et al. (2014b). Water stress and recovery in the performance of two Eucalyptus globulus clones: physiological and biochemical profiles. Physiol. Plant 150, 580-592. doi: $10.1111 /$ ppl.12110

Costa, P. R., and Garrido, S. (2004). Domoic acid accumulation in the sardine Sardina pilchardus and its relationship to Pseudo-nitzschia diatom ingestion. Mar. Ecol. Prog. Ser. 284, 261-268. doi: 10.3354/meps 284261

Cury, P. (2000). Small pelagics in upwelling systems: patterns of interaction and structural changes in "wasp-waist" ecosystems. ICES J. Mar. Sci. 57, 603-618. doi: $10.1006 /$ jmsc. 2000.0712

Domingues, I., Agra, A. R., Monaghan, K., Soares, A. M. V. M., and Nogueira, A. J. A. (2010). Cholinesterase and glutathione-S-transferase activities in freshwater invertebrates as biomarkers to assess pesticide contamination. Environ. Toxicol. Chem. 29, 5-18. doi: 10.1002/etc.23

DGRNSSM. (2012). Estatísticas da Pesca 2011. Lisboa.

Ellman, G. L., Courtney, K. D., Andres, V., and Featherstone, R. M. (1961). A new and rapid colorimetric determination of acetylcholinesterase activity. Biochem. Pharmacol. 7, 88-95. doi: 10.1016/0006-2952(61)90145-9

El Morsy, F. A. M., El-Sadaawy, M. M., Ahdy, H. H. H., Abdel-Fattah, L. M., El-Sikaily, A. M., Khaled, A., et al. (2013). Potential human health risks from toxic metals, polycyclic aromatic hydrocarbons, polychlorinated biphenyls, and organochlorine pesticides via canned fish consumption: estimation of target hazard quotients. J. Environ. Sci. Health A 48, 1470-1478. doi: 10.1080/10934529.2013.796782

Falcó, G., Llobet, J. M., Bocio, A., and Domingo, J. L. (2006). Daily intake of arsenic, cadmium, mercury, and lead by consumption of edible marine species. J. Agric. Food Chem. 54, 6106-6112. doi: 10.1021/jf0610110

Fang, J. K. H., Au, D. W. T., Wu, R. S. S., Chan, A. K. Y., Mok, H. O. L., and Shin, P. K. S. (2009). The use of physiological indices in rabbitfish Siganus oramin for monitoring of coastal pollution. Mar. Pollut. Bull. 58, 1229-1235. doi: 10.1016/j.marpolbul.2009.05.013

Fischer, P., Rademacher, K., and Kils, U. (1992). In situ investigations on the respiration and behaviour of the eelpout Zoarces viviparus under short-term hypoxia. Mar. Ecol. Prog. Ser. 88, 181-184. doi: 10.3354/meps088181

Fonseca, V. F., França, S., Serafim, A., Company, R., Lopes, B., Bebianno, M. J., et al. (2011). Multi-biomarker responses to estuarine habitat contamination in three fish species: Dicentrarchus labrax, Solea senegalensis and Pomatoschistus microps. Aquat. Toxicol. 102, 216-227. doi: 10.1016/j.aquatox.2011.01.018

Froescheis, O., Looser, R., Cailliet, G. M., Jarman, W. M., and Ballschmiter, K. (2000). The deep-sea as a final global sink of semivolatile persistent organic pollutants? Part I: PCBs in surface and deep-sea dwelling fish of the North and South Atlantic and the Monterey Bay Canyon (California). Chemosphere 40, 651-660. doi: 10.1016/S0045-6535(99)00461-0

Ganias, K. (2009). Linking sardine spawning dynamics to environmental variability. Estuar. Coast. Shelf Sci. 84, 402-408. doi: 10.1016/j.ecss.2009. 07.004

Garrido, S., Rosa, R., Ben-Hamadou, R., Cunha, M. E., Chícharo, M. A., and Lingen, C. D. (2008). Spatio-temporal variability in fatty acid trophic biomarkers in stomach contents and muscle of Iberian sardine (Sardina pilchardus) and its relationship with spawning. Mar. Biol. 154, 1053-1065. doi: 10.1007/s00227008-0999-7

Garrido, S., Rosa, R., Ben-Hamadou, R., Cunha, M. E., Chícharo, M. A., and van der Lingen, C. D. (2007). Effect of maternal fat reserves on the fatty acid composition of sardine (Sardina pilchardus) oocytes. Comp. Biochem. Physiol. B Biochem. Mol. Biol. 148, 398-409. doi: 10.1016/j.cbpb.2007.07.008

Habig, W. H., Pabst, M. J., and Jakoby, W. B. (1974). Glutathione S-transferases. The first step in mercapturic acid formation. J. Biol. Chem. 249, 7130-7139.

Heath, A. G. (1995). Water Pollution and Fish Physiology, 2nd Edn. Boca Raton, FL: CRC Press, Inc.

Heise, K., Estevez, M. S., Puntarulo, S., Galleano, M., Nikinmaa, M., Pörtner, H. O. et al. (2007). Effects of seasonal and latitudinal cold on oxidative stress parameters and activation of hypoxia inducible factor (HIF-1) in zoarcid fish. J. Comp Physiol. B 177, 765-777. doi: 10.1007/s00360-007-0173-4

Huggett, R. J., Kimerle, R. A., Mehrle, P. M., and Bergman, H. L., (eds.) (1992). Biomarkers: Biochemical, Physiological, and Histological Markers of Anthropogenic Stress. Boca Raton, FL: Lewis Publishers.

Ivar do Sul, J. A., and Costa, M. F. (2014). The present and future of microplastic pollution in the marine environment. Environ. Pollut. 185, 352-364. doi: 10.1016/j.envpol.2013.10.036

Josephy, P., and Mannervick, B. (2006). Molecular Toxicology, 2nd Edn. New York, NY: Oxford University Press.

Kaaya, A., Najimi, S., Ribera, D., Narbonne, J. F., and Moukrim, A. (1999). Characterization of glutathione S-transferases (GST) activities in Perna perna and Mytilus galloprovincialis used as a biomarker of pollution in the Agadir marine bay (South of Morocco). Bull. Environ. Contam. Toxicol. 62, 623-629. doi: $10.1007 / \mathrm{s} 001289900920$

Kleinkauf, A., Connor, L., Swarbreck, D., Levene, C., Walker, P., Johnson, P. J., et al. (2004). General condition biomarkers in relation to contaminant burden in European flounder (Platichthys flesus). Ecotox. Environ. Saf. 58, 335-355. doi: 10.1016/j.ecoenv.2004.03.007

Lam, P. K. S., and Gray, J. S. (2003). The use of biomarkers in environmental monitoring programmes. Mar. Pollut. Bull. 46, 182-186. doi: 10.1016/S0025326X(02)00449-6

Lau, P. S., Wong, H. L., and Garrigues, P. (2004). Seasonal variation in antioxidative responses and acetylcholinesterase activity in Perna viridis in eastern oceanic and western estuarine waters of Hong Kong. Cont. Shelf Res. 24, 1969-1987. doi: 10.1016/j.csr.2004.06.019

Leiniö, S., and Lehtonen, K. K. (2005). Seasonal variability in biomarkers in the bivalves Mytilus edulis and Macoma balthica from the northern Baltic 
Sea. Comp. Biochem. Physiol. C Toxicol. Pharmacol. 140, 408-421. doi: 10.1016/j.cca.2005.04.005

Le Pennec, G., and Le Pennec, M. (2003). Induction of glutathione-S-transferases in primary cultured digestive gland acini from the mollusk bivalve Pecten maximus (L.): application of a new cellular model in biomonitoring studies. Aquat. Toxicol. 64, 131-142. doi: 10.1016/S0166-445X(03)00041-9

Lionetto, M. G., Caricato, R., Giordano, M. E., Pascariello, M. F., Marinosci, L., and Schettino, T. (2003). Integrated use of biomarkers (acetylcholinesterase and antioxidant enzymes activities) in Mytilus galloprovincialis and Mullus barbatus in an Italian coastal marine area. Mar. Pollut. Bull. 46, 324-330. doi: 10.1016/S0025-326X(02)00403-4

Looser, R., Froescheis, O., Cailliet, G. M., Jarman, W. M., and Ballschmiter, K. (2000). The deep-sea as a final global sink of semivolatile persistent organic pollutants? Part II: organochlorine pesticides in surface and deep-sea dwelling fish of the North and South Atlantic and the Monterey Bay Canyon (California). Chemosphere 40, 661-670. doi: 10.1016/S0045-6535(99)00462-2

Loureiro, C., Castro, B. B., Cuco, A. P., Pedrosa, M. A., and Gonçalves, F. (2012). Life-history responses of salinity-tolerant and salinity-sensitive lineages of a stenohaline cladoceran do not confirm clonal differentiation. Hydrobiologia 702, 73-82. doi: 10.1007/s10750-012-1308-5

Lushchak, V. I. (2011). Environmentally induced oxidative stress in aquatic animals. Aquat. Toxicol. 101, 13-30. doi: 10.1016/j.aquatox.2010.10.006

Magalhães, M. J., and De Barros, M. C. (1987). The contamination of fish with chlorinated hydrocarbons in Portugal: continental coast and Azores islands. Environ. Monit. Assess. 8, 37-57. doi: 10.1007/BF00396606

Mai, C., Theobald, N., Lammel, G., and Hühnerfuss, H. (2013). Spatial, seasonal and vertical distributions of currently-used pesticides in the marine boundary layer of the North Sea. Atmos. Environ. 75, 92-102. doi: 10.1016/j.atmosenv. 2013.04.027

Manduzio, H., Monsinjon, T., Galap, C., Leboulenger, F., and Rocher, B. (2004). Seasonal variations in antioxidant defences in blue mussels Mytilus edulis collected from a polluted area: major contributions in gills of an inducible isoform of $\mathrm{Cu} / \mathrm{Zn}$-superoxide dismutase and of glutathione S-transferase. Aquat. Toxicol. 70, 83-93. doi: 10.1016/j.aquatox.2004.07.003

Marçalo, A., Mateus, L., Correia, J. H. D., Serra, P., Fryer, R., and Stratoudakis, Y. (2006). Sardine (Sardina pilchardus) stress reactions to purse seine fishing. Mar. Biol. 149, 1509-1518. doi: 10.1007/s00227-006-0277-5

Mendes, H. V., and Borges, M. F. (2006). "A sardinha no século XX: capturas e esforço de pesca," in Relatórios Científicos e Técnicos do IPIMAR, Vol. 32 (Algés: IPIMAR), 2-28.

Moreira, S. M., Lima, I., Ribeiro, R., and Guilhermino, L. (2006). Effects of estuarine sediment contamination on feeding and on key physiological functions of the polychaete Hediste diversicolor: laboratory and in situ assays. Aquat. Toxicol. 78, 186-201. doi: 10.1016/j.aquatox.2006.03.001

Napierska, D., Barsiene, J., Mulkiewicz, E., Podolska, M., and Rybakovas, A. (2009). Biomarker responses in flounder Platichthys flesus from the Polish coastal area of the Baltic Sea and applications in biomonitoring. Ecotoxicology 18, 846-859. doi: 10.1007/s10646-009-0328-Z

Nathan, S. S., Kalaivani, K., and Murugan, K. (2006). Effect of biopesticides on the lactate dehydrogenase (LDH) of the rice leaffolder, Cnaphalocrocis medinalis (Guenée) (Insecta: Lepidoptera: Pyralidae). Ecotoxicol. Environ. Saf. 65, 102-107. doi: 10.1016/j.ecoenv.2005.05.021

Nilsson, G. E., Crawley, N., Lunde, I. G., and Munday, P. L. (2009). Elevated temperature reduces the respiratory scope of coral reef fishes. Glob. Chang. Biol. 15, 1405-1412. doi: 10.1111/j.1365-2486.2008.01767.x

Nizzetto, L., Lohmann, R., Gioia, R., Jahnke, A., Temme, C., Dachs, J., et al. (2008). PAHs in air and seawater along a North-South Atlantic Transect: trends, processes and possible sources. Environ. Sci. Technol. 42, 1580-1585. doi: $10.1021 /$ es0717414

Nunes, B. (2011). The use of cholinesterases in ecotoxicology. Rev. Env. Contam. Toxicol. 212, 29-59. doi: 10.1007/978-1-4419-8453-1_2

Nunes, C., Silva, A., Soares, E., and Ganias, K. (2011). The use of hepatic and somatic indices and histological information to characterize the reproductive dynamics of Atlantic sardine Sardina pilchardus from the Portuguese coast. Mar. Coast. Fish. 3, 127-144. doi: 10.1080/19425120.2011.556911

Oliva, M., José Vicente, J., Gravato, C., Guilhermino, L., and Dolores GalindoRiaño, M. (2012). Oxidative stress biomarkers in Senegal sole, Solea senegalensis, to assess the impact of heavy metal pollution in a Huelva estuary (SW Spain): Seasonal and spatial variation. Ecotoxicol. Environ. Saf. 75, 151-162.
Padmini, E., and Vijaya Geetha, B. (2009). Impact of season on liver mitochondrial oxidative stress and the expression of HSP70 in grey mullets from contaminated estuary. Ecotoxicology 18, 304-311. doi: 10.1007/s10646-0080282-1

Palomera, I., Olivar, M. P., Salat, J., Sabatés, A., Coll, M., García, A., et al. (2007). Small pelagic fish in the NW Mediterranean Sea: an ecological review. Prog. Oceanogr. 74, 377-396. doi: 10.1016/j.pocean.2007.04.012

Pavlović, S. Z., Borković Mitić, S. S., Radovanović, T. B., Perendija, B. R., Despotović, S. G., Gavrić, J. P., et al. (2010). Seasonal variations of the activity of antioxidant defense enzymes in the red mullet (Mullus barbatus 1.) from the Adriatic Sea. Mar. Drugs 8, 413-428. doi: 10.3390/ md8030413

Peakall, D. (1992). Animal Biomarkers as Pollution Indicators. London: Chapman and Hall. doi: 10.1007/978-94-011-2346-4

Peixoto, F., Alves-Fernandes, D., Santos, D., and Fontaínhas-Fernandes, A. (2006). Toxicological effects of oxyfluorfen on oxidative stress enzymes in tilapia Oreochromis niloticus. Pestic. Biochem. Physiol. 85, 91-96. doi: 10.1016/j.pestbp. 2005.10.007

Peters, L., Porte, C., Albaigés, J., and Livingstone, D. (1994). 7-Ethoxyresorufin O-deethylase (EROD) and antioxidant enzyme activities in larvae of sardine (Sardina pilchardus) from the north coast of Spain. Mar. Pollut. Bull. 28, 299-304. doi: 10.1016/0025-326X(94)90154-6

Quinn, G., and Keough, M. J. (2002). Experimental Design and Data Analysis for Biologists. Cambridge: Cambridge University Press. doi: 10.1017/ CBO9780511806384

Ramos, A. S., Antunes, S. C., Gonçalves, F., and Nunes, B. (2014). The Gooseneck Barnacle (Pollicipes pollicipes) as a candidate sentinel species for coastal contamination. Arch. Environ. Contam. Toxicol. 66, 317-326. doi: 10.1007/s00244-0139978-1

Regoli, F. (1998). Trace metals and antioxidant enzymes in gills and digestive gland of the Mediterranean mussel Mytilus galloprovincialis. Arch. Environ. Contam. Toxicol. 34, 48-63. doi: 10.1007/s002449900285

Roose, P., and Brinkman, U. A. T. (2005). Monitoring organic microcontaminants in the marine environment: principles, programmes and progress. TrAC Trends Anal. Chem. 24, 897-926. doi: 10.1016/j.trac.2005.10.007

Schulz-Bull, D., Petrick, G., Bruhn, R., and Duinker, J. (1998). Chlorobiphenyls (PCB) and PAHs in water masses of the northern North Atlantic. Mar. Chem. 61, 101-114. doi: 10.1016/S0304-4203(98)00010-3

Sheehan, D., and Power, A. (1999). Effects of seasonality on xenobiotic and antioxidant defence mechanisms of bivalve molluscs. Comp. Biochem. Physiol. C Pharmacol. Toxicol. Endocrinol. 123, 193-199. doi: 10.1016/S07428413(99)00033-X

Silva, A., Santos, M., Caneco, B., Pestana, G., Porteiro, C., Carrera, P., et al. (2006) Temporal and geographic variability of sardine maturity at length in the northeastern Atlantic and the western Mediterranean. ICES J. Mar. Sci. 63, 663-676 doi: 10.1016/j.icesjms.2006.01.005

Sinovčić, G., Keč, V. Č., and Zorica, B. (2008). Population structure, size at maturity and condition of sardine, Sardina pilchardus (Walb., 1792), in the nursery ground of the eastern Adriatic Sea (Krka River Estuary, Croatia). Estuar. Coast. Shelf Sci. 76, 739-744. doi: 10.1016/j.ecss.2007.07.037

Sol, S. Y., Johnson, L. L., Boyd, D., Olson, O. P., Lomax, D. P., and Collier, T. K. (2008). Relationships between anthropogenic chemical contaminant exposure and associated changes in reproductive parameters in male English sole (Parophrys vetulus) collected from Hylebos Waterway, Puget Sound, Washington. Arch. Environ. Contam. Toxicol. 55, 627-638. doi: 10.1007/s00244008-9140-7

Somarakis, S., Ganias, K., Tserpes, G., and Koutsikopoulos, C. (2004). Ovarian allometry and the use of the gonosomatic index: a case study in the Mediterranean sardine, Sardina pilchardus. Mar. Biol. 146, 181-189. doi: 10.1007/s00227-004-1419-2

Stagg, R. M. (1998). The development of an international programme for monitoring the biological effects of contaminants in the OSPAR convention area. Mar. Environ. Res. 46, 307-313. doi: 10.1016/S0141-1136(98)00013-0

Stanic, B., Andric, N., Zoric, S., Grubor-Lajsic, G., and Kovacevic, R. (2006) Assessing pollution in the Danube River near Novi Sad (Serbia) using several biomarkers in sterlet (Acipenser ruthenus L.). Ecotoxicol. Environ. Saf. 65, 395-402. doi: 10.1016/j.ecoenv.2005.08.005

Stratoudakis, Y., and Silva, A. (2001). A pescaria da sardinha, uma prioridade da investigação. Divulg. IPIMAR 16, 1-4. 
Suthers, I. M. (1998). Bigger? Fatter? Or is faster growth better? Considerations on condition in larval and juvenile coral-reef fish. Austral Ecol. 23, 265-273. doi: 10.1111/j.1442-9993.1998.tb00730.x

Ter Braak, C. J. (1995). "Ordination," in Data Analysis in Community and Landscape Ecology, eds R. H. Jongman, C. J. Ter Braak, and O. F. van Tongeren (Cambridge: Cambridge University Press), 91-173. doi: 10.1017/CBO9780511525575.007

Thébault, M. T. (1984). Lactate content and lactate dehydrogenase activity in Palaemon serratus abdominal muscle during temperature changes. J. Comp. Physiol. B 154, 85-89. doi: 10.1007/BF00683220

Timbrell, J. A. (1998). Biomarkers in toxicology. Toxicology 129, 1-12. doi: 10.1016/S0300-483X(98)00058-4

Tocher, D. R. (2003). Metabolism and functions of lipids and fatty acids in teleost fish. Rev. Fish. Sci. 11, 107-184. doi: 10.1080/713610925

Trujillo-Jiménez, P., Sedeño-Díaz, J. E., Camargo, J. A., and López-López, E. (2011). Assessing environmental conditions of the Río Champotón (México) using diverse indices and biomarkers in the fish Astyanax aeneus (Günther, 1860). Ecol. Indic. 11, 1636-1646. doi: 10.1016/j.ecolind.2011. 04.007

Tsangaris, C., Kormas, K., Strogyloudi, E., Hatzianestis, I., Neofitou, C., Andral, B., et al. (2010). Multiple biomarkers of pollution effects in caged mussels on the Greek coastline. Comp. Biochem. Physiol. C Toxicol. Pharmacol. 151, 369-378. doi: 10.1016/j.cbpc.2009.12.009

van der Oost, R., Beyer, J., and Vermeulen, N. P. (2003). Fish bioaccumulation and biomarkers in environmental risk assessment: a review. Environ. Toxicol. Pharmacol. 13, 57-149. doi: 10.1016/S1382-6689(02) 00126-6

Vassault, A. (1983). "Lactate dehydrogenase," in Methods of Enzymatic Analysis Vol III Enzymes: Oxireductases Transferases, ed H. O. Bergmeyer (New York, NY: Academic Press), 118-126.

Vidal, M.-L., Bassères, A., and Narbonne, J.-F. (2002). Seasonal variations of pollution biomarkers in two populations of Corbicula fluminea (Müller). Comp. Biochem. Physiol. C Toxicol. Pharmacol. 131, 133-151. doi: 10.1016/S15320456(01)00291-5

Vidal-Liñán, L., Bellas, J., Campillo, J. A., and Beiras, R. (2010). Integrated use of antioxidant enzymes in mussels, Mytilus galloprovincialis, for monitoring pollution in highly productive coastal areas of Galicia (NW Spain). Chemosphere 78, 265-272. doi: 10.1016/j.chemosphere.2009.10.060

Vinagre, C., Madeira, D., Narciso, L., Cabral, H. N., and Diniz, M. (2012). Effect of temperature on oxidative stress in fish: lipid peroxidation and catalase activity in the muscle of juvenile seabass, Dicentrarchus labrax. Ecol. Indic. 23, 274-279. doi: 10.1016/j.ecolind.2012.04.009
Wang, W., and Ballatori, N. (1998). Endogenous glutathione conjugates: occurrence and biological functions. Pharmacol. Rev. 50, 335-356.

Ware, D. M., and Thomson, R. E. (1991). Link between long-term variability in upwelling and fish production in the Northeast Pacific Ocean. Can. J. Fish. Aquat. Sci. 48, 2296-2306. doi: 10.1139/f91-270

Weigel, S., Bester, K., and Hühnerfuss, H. (2005). Identification and quantification of pesticides, industrial chemicals, and organobromine compounds of medium to high polarity in the North Sea. Mar. Pollut. Bull. 50, 252-263. doi: 10.1016/j.marpolbul.2004.10.011

Wright, S. L., Rowe, D., Thompson, R. C., and Galloway, T. S. (2013) Microplastic ingestion decreases energy reserves in marine worms. Curr. Biol. 23, R1031-R1033. doi: 10.1016/j.cub.2013.10.068

Wu, R. S. S., and Lam, P. K. S. (1997). Glucose-6-phosphate dehydrogenase and lactate dehydrogenase in the green-lipped mussel (Perna viridis): possible biomarkers for hypoxia in the marine environment. Water Res. 31, 2797-2801. doi: 10.1016/S0043-1354(97)00116-4

Wurl, O., and Obbard, J. P. (2004). A review of pollutants in the sea-surface microlayer (SML): a unique habitat for marine organisms. Mar. Pollut. Bull. 48, 1016-1030. doi: 10.1016/j.marpolbul.2004.03.016

Yang, T. H., Lai, N. C., Graham, J. B., and Somero, G. N. (1992). Respiratory, blood, and heart enzymatic adaptations of Sebastolobus alascanus (Scorpaenidae; Teleostei) to the oxygen minimum zone: a comparative study. Biol. Bull. 183, 490-499. doi: $10.2307 / 1542026$

Conflict of Interest Statement: The authors declare that the research was conducted in the absence of any commercial or financial relationships that could be construed as a potential conflict of interest.

Received: 10 November 2014; accepted: 28 January 2015; published online: 24 February 2015.

Citation: Nunes BS, Travasso R, Gonçalves F and Castro BB (2015) Biochemical and physiological modifications in tissues of Sardina pilchardus: spatial and temporal patterns as a baseline for biomonitoring studies. Front. Environ. Sci. 3:7. doi: 10.3389/ fenvs.2015.00007

This article was submitted to Environmental Toxicology, a section of the journal Frontiers in Environmental Science.

Copyright (c) 2015 Nunes, Travasso, Gonçalves and Castro. This is an open-access article distributed under the terms of the Creative Commons Attribution License (CC BY). The use, distribution or reproduction in other forums is permitted, provided the original author(s) or licensor are credited and that the original publication in this journal is cited, in accordance with accepted academic practice. No use, distribution or reproduction is permitted which does not comply with these terms. 